\title{
Urban health nexus with COVID-19 preparedness and response in Africa: rapid scoping review of the early evidence.
}

Robert Kaba Alhassan ( $\sim$ ralhassan@uhas.edu.gh)

\section{Research article}

Keywords: COVID-19, pandemic, response strategies, Africa, urban health.

Posted Date: September 21st, 2020

DOI: https://doi.org/10.21203/rs.3.rs-79685/v1

License: (c) (1) This work is licensed under a Creative Commons Attribution 4.0 International License. Read Full License 


\section{Abstract}

Background: Severe acute respiratory syndrome coronavirus 2 (SARS-CoV-2) also called COVID-19 was first reported in the African continent on $14^{\text {th }}$ February 2020 , in Egypt. As at $24^{\text {th }}$ August 2020, the continent reported a total of 1,189,526 cases; 27,798 deaths and 907,822 recoveries. Urban cities in African have suffered the brunt of COVID-19; meanwhile, response strategies by African countries have largely been condemned as "one-size-fit-all" approach.

Objective: This paper synthesized and analyzed early evidence on the nexus between urban health and COVID-19 preparedness and response in Africa.

Methods: Rapid scoping review of empirical and grey literature was done using data sources such as ScienceDirect, GoogleScholar, PubMed, HINARI and official websites of WHO and Africa CDC. Out of over 6,000 search output, 24 full articles, reviews and commentaries were finally synthesized analyzed qualitatively based on relevance and quality, guided by the PRISMA flow chart (2009).

Results: Over 70\% of the 24 articles reported on COVID-19 response strategies across Africa; $29 \%$ of the articles reported on preparedness towards COVID-19 while $41 \%$ reported on the nexus between urbanization and COVID-19; $37 \%$ of the publications were full text empirical studies while the remaining $63 \%$ were either commentaries, reviews or editorials. It was found that urban cities remain epicentres for COVID-19 in Africa. Even though some successes have been recorded in Africa in respect of the COVID-19 fight, the continent's response strategies are largely a "one-size-fit all" approach. In effect, adoption of "Western elitist" mitigating measures for COVID-19 resulted in excesses and spillover effects on individuals, families and economies in Africa.

Conclusion: Africa needs to increase commitment to health systems strengthening through context-specific interventions in addition to prioritization of pandemic preparedness over response. Likewise, improved economic resilience and proper urban planning will help African countries to respond better to future public health emergencies.

\section{Background}

Severe acute respiratory syndrome coronavirus 2 (SARS-CoV-2) also called COVID-19 first reported in China in the latter part of 2019 has so far infected over 20 million people, killed over 700,000 globally ${ }^{[1]}$ and rapidly overwhelmed health systems globally. COVID-19 was first reported in the African continent on 14th February 2020, in Egypt ${ }^{[1]}$. As at 24th August 2020, the continent reported a total of 1,189,526 cases; 27,798 deaths and 907,822 recoveries ${ }^{\text {[2] }}$. Southern Africa region remains the worst affected with approximately 650,500 cases followed by North Africa with 212,300 recorded cases; West Africa with 155,300 recorded cases and East Africa with 118,800 recorded cases. The least affected region being central Africa with approximately 52,600 recorded cases [2] Urban cities in this era of globalization are facing a triple health burden of non-communicable and communicable diseases including COVID-19 ${ }^{[3,4]}$. Evidence suggests that most emerging infectious diseases either originate in urban settings (e.g. emergence of COVID-19 in Wuhan, China) or they rapidly propagate because of urbanization ${ }^{[5,6]}$.

Urban cities easily become epicenters for global pandemics due to several factors key of them being poor housing and urban sanitation. In the early COVID-19 literature poor housing has been identified as a major cause of COVID-19 spread due to poor ventilation and communal living [7]. Strict adherence to personal hygiene practices and social distancing among urban dwellers is also low because of insufficient social amenities ${ }^{[8,9]}$. It is estimated that barely $56 \%$ of urban populations in Africa have access to pipe water ${ }^{[10,11]}$ making routine handwashing practically impossible especially among the urban poor.

Similarly, population density in urban cities impedes strict adherence to social distancing in the wake of COVID-19 ${ }^{[7-9,12]}$. The situation is aggravated by the inability of health authorities to effectively trace the routes and circulation of infected people in urban settlements because of poor street naming and address systems even in national capitals. Consequently, contact tracing under these circumstances has largely been unsuccessfully thus resulting in early and unabated community spread of COVID-19 [12]. Alegbeleye ${ }^{[8]}$ intimated that observing social distancing in many urban communities in Africa is virtually not feasible due to high urban population densities coupled with contrary African societal and cultural norms which are inherently communal and do not respect social distancing protocols.

Furthermore, in many African countries, urban poverty, illiteracy, ignorance, misconceptions and cultural belief systems have negatively affected the fight against global pandemics including COVID-19 and in most cases promoted easy spread of these pandemics. Spiritual dimensions to global pandemics have also reversed gains made by African countries on COVID-19 and during Ebola outbreak in Liberia ${ }^{[13,14]}$, Sierra Leone ${ }^{[15,16]}$ and Guinea ${ }^{[17,18]}$ where index cases and families prefer seeking care from faith healers and spiritualists instead of mainstream healthcare systems.

Additionally, rural-urban labour mobility historically promotes rapid spread of pandemics in urban settings ${ }^{[19]}$. In the case of COVID-19, partial lockdown in the two biggest cities in Ghana witnessed huge labour migrants escaping these cities to rural areas on the eve of the lockdown. This migrant mobility raised concerns on the effectiveness of the lockdown measure since carriers of the virus probably escaped with it into other parts of the country [20,21]. Similarly, unabated rural-urban migration for better health, social and economic opportunities in urban cities has resulted in overstretching of existing health infrastructure in many African countries. It was predicted in the early days of COVID-19 that in the US at least 200,000 intensive care unit (ICU) beds were needed in the case of a moderate outbreak of the pandemic ${ }^{[22]}$. Uganda on the other hand had $55 \mathrm{ICU}$ beds in 12 operational units ${ }^{[23]}$ with $80 \%$ of these ICU beds located in the capital Kampala ${ }^{[24]}$. Likewise, in Ghana the number of isolation and quarantine centres remain inadequate given the COVID-19 case counts ${ }^{[25]}$ and the fact that the country is only second to Nigeria in terms of case count in the West-African sub-region ${ }^{[2]}$. Limited health infrastructure therefore remains a major challenge to fragile health systems in Africa as the continent continues the battle against COVID-19. See Table 1 on index COVID-19 cases in selected African countries. 
Table 1

Index cases of COVID-19 in selected African Countries

\begin{tabular}{|lll|}
\hline Country & Date & Case History \\
\hline China (Global index) & 17th November, 2020 & 55-year-old from Wuhan in the Hubei province \\
\hline Algeria & 25th February, 2020 & Italian national who travelled to Algeria \\
\hline Egypt & 14th February, 2020 & Chinese national \\
\hline Ethiopia & 13th March, 2020 & Japanese national travelling from Japan to Burkina Faso \\
\hline Ghana & 12th March, 2020 & Two cases imported from Norway \& Turkey \\
\hline Ivory Coast & 11th March, 2020 & Ivorian traveling from Italy \\
\hline Kenya & 12th March, 2020 & Kenyan traveling from US via UK \\
\hline Nigeria & 27th February, 2020 & Italian citizen from Milan to Lagos \\
\hline Source: Aggregated by Author based on the reviewed literature (August, 2020) \\
\hline
\end{tabular}

This scoping review synthesized and analyzed available evidence on the nexus between urban health and COVID-19 preparedness and response in Africa. This rapid review is expected to contribute to early scientific evidence on the COVID-19 pandemic and further inform health policy dialogues on post-COVID-19 interventions to improve health systems resilience against future public health emergencies in Africa and across the globe.

\section{Methods}

\section{Review rationale and justification}

This is a rapid scoping review to aimed at understanding the scope and body of literature on the nexus between urbanization and COVID-19 preparedness and response Africa.

\section{Review question development}

In line with Joanabriggs Institute (JBI) guideline for comprehensive systematic reviews (see Supplementary File 1), the review question and components were based on population, concept and context principles. The population in the milieu of this review is the various countries and their health systems while the concept is the COVID-19 preparedness and response strategies in Africa.

\section{Eligibility and exclusion criteria}

The Preferred Reporting Items for Systematic reviews and Meta-Analyses (PRISMA) flow chart (2009) was used to determine the edibility criteria for literature inclusion and exclusion (see Fig. 1). Reviewed literature comprised of peer-reviewed publications and grey literature on COVID-19 preparedness and response strategies in Africa and the relationship with urbanization. Search for relevant literature was done in the English language using key words/terms and the Boolean search terms "and" "or" and "not". The search terms and key words were: "Coronavirus", "Coronavirus disease-19", "COVID-19", "preparedness", "response strategies", "urban health", "urbanization", "Africa”, "health systems", "fragile health systems" and "one-size-fits-all”. Exclusion criteria for the reviewed publications were: publications not written in English language, not published on COVID-19 and not focused on Africa.

\section{Information sources and literature selection}

Electronic search was conducted using relevant databases such as PubMed, ScienceDirect, GoogleScholar, and HINARI. Additionally, grey literature from official websites of international institutions such as the World Health Organization (WHO) and Africa Centres for Disease Control (CDC) were used to access relevant publications. Time frame for the literature was since the outbreak of COVID-19 in December, 2019 till date. Snowballing technique was also used where reference list of accessed publications was further traced for relevant publications up to saturation.

\section{Screening and literature quality}

JBI Critical Appraisal Checklist for Systematic Reviews and Research Syntheses was used to promote quality in the review process. Publications that did not meet at least $70 \%$ of the set criterion were dropped from the final synthesis and analysis. In the case of empirical peer-reviewed publications, the quality checks included: publications having explicitly stated research questions/objectives/aims, inclusion/exclusion criteria, literature search sources, study setting and study subjects. Other quality checks were methodology employed, outcome measures and confounders, appropriateness of statistical analysis. The remaining quality checks were: recognized limitations and mitigating measures, ethical considerations and interpretation of findings. Additionally, published literature should have been peer-reviewed (or undergoing review in pre-print) in at least Scopus-indexed journal. Commentaries, perspectives and reviews were included because of the paucity of publications on COVID-19 due to its novel nature at time of this review.

\section{Data extraction and analysis}

Data extraction from the accessed literature was done using an extraction form developed by the authors based on JBI guidelines for scoping reviews. For objectivity and reduction of chance effect bias, the data extraction was concurrently done by two independent reviewers who later reconciled the extracted information for convergence. Synthesis and analysis were guided by the recurrent themes from the reviewed literature. Where applicable, data extraction categories included: authors, year of publication, study location/context, study type and participants/subjects. Main thematic areas that emerged from the review on COVID-19 were: preparedness, response strategies and the COVID-19 nexus with urban health. Key findings/conclusions and thrust of each publication were also captured in the extraction form (see Table 3). 
Table 3

Data extraction and review summary

\begin{tabular}{|c|c|c|c|c|c|c|c|c|}
\hline \multicolumn{5}{|c|}{ Authorship and publications information } & \multicolumn{3}{|c|}{ Key perspectives on COVID-19 } & \multirow{2}{*}{$\begin{array}{l}\text { Findings/conclusions on } \\
\text { COVID-19 } \\
\text { Key findings }\end{array}$} \\
\hline Author & Year & Location/context & Study type & Participants & Preparedness & Response & Urbanization & \\
\hline Afulani et al* & 2020 & Ghana & $\begin{array}{l}\text { Empirical } \\
\text { article } \\
\text { (Cross- } \\
\text { sectional) }\end{array}$ & $\begin{array}{l}\mathrm{HCWs}(\mathrm{n}= \\
472)\end{array}$ & $x$ & & & $\begin{array}{l}\text { Increase HCWs' } \\
\text { preparedness to respond to } \\
\text { COVID-19/pandemics }\end{array}$ \\
\hline Ahmed et al & 2020 & Global & $\begin{array}{l}\text { Empirical } \\
\text { article Cross- } \\
\text { sectional }\end{array}$ & $\begin{array}{l}\text { Dentist }(n= \\
669)\end{array}$ & & $\mathrm{x}$ & & $\begin{array}{l}\text { Truncated dental care } \\
\text { services }\end{array}$ \\
\hline Alegbeleye et al & 2020 & SSA & $\begin{array}{l}\text { Systematic } \\
\text { review }\end{array}$ & HCWs & & $\mathrm{x}$ & & $\begin{array}{l}\text { Non-compliance with } \\
\text { protocols }\end{array}$ \\
\hline Ayebare et al & 2020 & SSA & Review & $\begin{array}{l}\text { Health } \\
\text { system }\end{array}$ & $\mathrm{x}$ & & & $\begin{array}{l}\text { Leveraging Ebola } \\
\text { experiences to combat } \\
\text { COVID-19 }\end{array}$ \\
\hline Bong et al & 2020 & LMICs & Review & $\begin{array}{l}\text { Health } \\
\text { system }\end{array}$ & $\mathrm{x}$ & $\mathrm{x}$ & & Fragile health systems \\
\hline Cash et al & 2020 & LMICs & Perspective & $\begin{array}{l}\text { Health } \\
\text { system }\end{array}$ & & $\mathrm{x}$ & $x$ & Fragile economies \\
\hline Chersich et al & 2020 & Africa & Review & HCWs & & $x$ & $x$ & $\begin{array}{l}\text { Fragile health } \\
\text { economies/health systems }\end{array}$ \\
\hline Estifanos et al & 2020 & Ethiopia & Commentary & Community & & $x$ & & $\begin{array}{l}\text { Political and socio- } \\
\text { economic crisis from } \\
\text { lockdown }\end{array}$ \\
\hline Gilbert et al & 2020 & Africa & $\begin{array}{l}\text { Empirical } \\
\text { article (Air } \\
\text { travel data) }\end{array}$ & $\begin{array}{l}\text { Countries } \\
(n=10)\end{array}$ & $x$ & & & $\begin{array}{l}\text { Low capacity, high } \\
\text { vulnerability }\end{array}$ \\
\hline Iwuoha et al & 2020 & Nigeria & $\begin{array}{l}\text { Empirical } \\
\text { article } \\
\text { (Descriptive) }\end{array}$ & $\begin{array}{l}\text { Urban slum } \\
\text { dwellers }\end{array}$ & & $x$ & $x$ & $\begin{array}{l}\text { Elitist/western contexts of } \\
\text { Covid-19 lockdown and } \\
\text { physical distancing }\end{array}$ \\
\hline Junior et al & 2020 & Ghana & $\begin{array}{l}\text { Empirical } \\
\text { article Cross- } \\
\text { sectional }\end{array}$ & $\begin{array}{l}\text { Public } \\
\text { transport } \\
\text { vehicles }(\mathrm{n} \\
=850)\end{array}$ & & $x$ & $x$ & $\begin{array}{l}\text { Low compliance with } \\
\text { protocols }\end{array}$ \\
\hline Kigatiira et al & 2020 & Kenya & $\begin{array}{l}\text { Empirical } \\
\text { article (Case } \\
\text { study) }\end{array}$ & $\begin{array}{l}\text { Public } \\
\text { motorcycle } \\
\text { riders }(\mathrm{n}= \\
17)\end{array}$ & & $x$ & $x$ & $\begin{array}{l}\text { Fear-based } \\
\text { messaging/communication }\end{array}$ \\
\hline Lee et al & 2020 & Global & Commentary & $\begin{array}{l}\text { Urban } \\
\text { populations }\end{array}$ & $x$ & & $x$ & $\begin{array}{l}\text { Urbanization and } \\
\text { population effects on } \\
\text { health systems }\end{array}$ \\
\hline $\begin{array}{l}\text { Martinez-Alvarez } \\
\text { et al }\end{array}$ & 2020 & SSA & Commentary & $\begin{array}{l}\text { Health } \\
\text { system }\end{array}$ & & & $x$ & $\begin{array}{l}\text { Response capacity of } \\
\text { resource-poor countries }\end{array}$ \\
\hline Nachega et al & 2020 & DRC & Perspective & $\begin{array}{l}\text { Health } \\
\text { system }\end{array}$ & & $x$ & & $\begin{array}{l}\text { Economy/infectious and } \\
\text { noninfectious diseases }\end{array}$ \\
\hline $\begin{array}{l}\text { Nepomnyashchiy } \\
\text { et al }\end{array}$ & 2020 & Liberia & Commentary & $\mathrm{CHWs}$ & & $x$ & & $\begin{array}{l}\text { Investment in } \mathrm{CHWs} \text { and } \\
\mathrm{PHC}\end{array}$ \\
\hline Nyarko et al & 2020 & Global & Review & $\begin{array}{l}\text { Country } \\
\text { economies }\end{array}$ & & $x$ & $x$ & $\begin{array}{l}\text { Impact of lockdowns on } \\
\text { economies }\end{array}$ \\
\hline Paintsil et al & 2020 & Africa & Viewpoint & $\begin{array}{l}\text { Heath } \\
\text { system }\end{array}$ & $x$ & $x$ & & $\begin{array}{l}\text { Low capacity of Africa } \\
\text { towards COVID- } 19 \text { fight }\end{array}$ \\
\hline Rosenthal et al & 2020 & Africa & Editorial & $\begin{array}{l}\text { Health } \\
\text { system }\end{array}$ & & $x$ & & $\begin{array}{l}\text { COVID-19 mitigating } \\
\text { measures }\end{array}$ \\
\hline Jewell et al & 2020 & SSA & $\begin{array}{l}\text { Empirical } \\
\text { article } \\
\text { (Modeling)+ }\end{array}$ & $\begin{array}{l}\text { HIV/AIDS } \\
\text { populations }\end{array}$ & $x$ & & & $\begin{array}{l}\text { Interruption in supply of } \\
\text { ARTs/services due to } \\
\text { COVID-19 }\end{array}$ \\
\hline Joska et al & 2020 & S. Africa & Field notes & $\begin{array}{l}\text { PLWHIV } \\
\text { (women) }\end{array}$ & & $x$ & & $\begin{array}{l}\text { Mental health } \\
\text { consequences of COVID-19 }\end{array}$ \\
\hline
\end{tabular}

Source: Aggregated by Authors based on reviewed literature (2020); Legend: *Pre-print article; ${ }^{* *}$ COVID-19 safety and preventive protocols include Wearing of nose masks, use of alcohol-based sanitizer, social distancing, hand hygiene/washing; +Mathematical modelling 


\begin{tabular}{|c|c|c|c|c|c|c|c|c|}
\hline \multicolumn{5}{|c|}{ Authorship and publications information } & \multicolumn{3}{|c|}{ Key perspectives on COVID-19 } & \multirow{2}{*}{$\begin{array}{l}\text { Findings/conclusions on } \\
\text { COVID-19 } \\
\text { Mental health impact of } \\
\text { COVID-19 on urban adults }\end{array}$} \\
\hline Kim et al* & 2020 & S. Africa & $\begin{array}{l}\text { Empirical } \\
\text { article } \\
\text { (Modeling)+ }\end{array}$ & $\begin{array}{l}\text { Adults }(\mathrm{n}= \\
957)\end{array}$ & & $x$ & $x$ & \\
\hline Akseer et al & 2020 & LMICs & $\begin{array}{l}\text { Review } \\
\text { article }\end{array}$ & $\begin{array}{l}\text { Women and } \\
\text { children }\end{array}$ & & $\mathrm{x}$ & $\mathrm{x}$ & $\begin{array}{l}\text { COVID-19 direct effect on } \\
\text { maternal/child health } \\
\text { nutrition }\end{array}$ \\
\hline Robertson et al & 2020 & LMICs & $\begin{array}{l}\text { Empirical } \\
\text { article } \\
\text { (Modeling)+ }\end{array}$ & $\begin{array}{l}\text { Women and } \\
\text { children }\end{array}$ & & $\mathrm{X}$ & & $\begin{array}{l}\text { Indirect effects of COVID-19 } \\
\text { on maternal and child } \\
\text { mortality }\end{array}$ \\
\hline Total & & & & & $7 / 24(29 \%)$ & $\begin{array}{l}18 / 24 \\
(75 \%)\end{array}$ & $10 / 24(41 \%)$ & \\
\hline
\end{tabular}

Source: Aggregated by Authors based on reviewed literature (2020); Legend: *Pre-print article; $* \star C O V I D-19$ safety and preventive protocols include Wearing of nose masks, use of alcohol-based sanitizer, social distancing, hand hygiene/washing; +Mathematical modelling

\section{Results}

\section{Synthesis of results}

Out of over 6,000 initial search output, 24 full-text empirical, review and commentary publications were finally considered. In all 24 publications were synthesized and analyzed based on relevance to the African context and quality. All publications were published in 2020. Nine (9) out the 24 publications were empirical studies which were mostly cross-sectional descriptive studies with one being a case study and three (3) mathematical modeling based on secondary data. The highest sample size for the publications based on primary data was 850 and lowest was 10.

In terms of country distributions, most of the publications focused on Africa as a continent $(n=3)$ followed by SSA $(n=4)$. Four $(4)$ publications focused on global context with interest on Africa and other low- and middle-income countries (LMICs). A few others specifically focused on Ghana ( $n=2)$, Ethiopia ( $n=1)$, Nigeria $(n=1)$, Kenya $(n=1)$, Democratic Republic of Congo $(\operatorname{DRC})(n=1)$, South Africa $(n=2)$ and Liberia $(n=1)$.

With respect to the type of study participants investigated, majority of the publications focused broadly on health systems ( $n=7)$ followed by health care workers (HCWs) such as community health workers $(n=4)$ and dentists $(n=1)$. Other publications focused on community participants such as slum/urban dwellers, women, children and People Living with HIV (PLWHIV) $(n=7)$. Two publications concentrated on public transport vehicles and motorcycle riders while two others broadly investigated COVID-19 impact on economies of countries in Africa (see Table 2). 


\begin{tabular}{|c|c|c|}
\hline Dimensions & Challenges & Opportunities \\
\hline \multirow[t]{3}{*}{ Urban population density } & $\begin{array}{l}\text { - Ease of disease spread between humans due to } \\
\text { congestions }\end{array}$ & $\begin{array}{l}\text { - Urban planning/design should factor in health emergency } \\
\text { preparedness }\end{array}$ \\
\hline & - Difficulties in contact tracing & \multirow{2}{*}{$\begin{array}{l}\text { - Leveraging technological advances for more effective } \\
\text { contact tracing and health supplies distribution (i.e. medical } \\
\text { drones) }\end{array}$} \\
\hline & - Urban inequalities resulting in poor housing/environments & \\
\hline \multirow{2}{*}{$\begin{array}{l}\text { Urban } \\
\text { transportation/mobility }\end{array}$} & - Congestions in public transport systems & \multirow{2}{*}{$\begin{array}{l}\text { - Cities with efficient transport networks can be used to } \\
\text { rapidly move supplies to outbreak in epicentres }\end{array}$} \\
\hline & - Inefficiency in public transport system & \\
\hline \multirow[t]{2}{*}{$\begin{array}{l}\text { Interface between animals } \\
\text { and humans }\end{array}$} & $\begin{array}{l}\text { Poor sanitation in urban slums with high exposure of } \\
\text { humans to rodents, unvaccinated animals and other animal } \\
\text { vectors }\end{array}$ & $\begin{array}{l}\text { - Improved sanitation and rodent control including } \\
\text { vaccination of domestic animals for common zoonotic } \\
\text { infections }\end{array}$ \\
\hline & $\begin{array}{l}\text { - Expansion into previously untouched ecosystems and } \\
\text { encounters with wildlife via food markets }\end{array}$ & $\begin{array}{l}\text { - Enhanced regulation of fresh markets and slaughter } \\
\text { houses }\end{array}$ \\
\hline \multirow[t]{2}{*}{$\begin{array}{l}\text { Governance by local } \\
\text { authorities }\end{array}$} & $\begin{array}{l}\text { - Insufficient epidemic preparedness capacities at local } \\
\text { government levels }\end{array}$ & $\begin{array}{l}\text { - Increased investment in local governance for self-reliance } \\
\text { in health emergency response }\end{array}$ \\
\hline & - Reliance on national level for response measures & $\begin{array}{l}\text { - Effective decentralization of local governance and health } \\
\text { systems }\end{array}$ \\
\hline \multirow{3}{*}{$\begin{array}{l}\text { High mobility of urban } \\
\text { populations }\end{array}$} & -Unrelenting rural-urban migration & \multirow{3}{*}{$\begin{array}{l}\text { - Evidence-based points of entry measures and exit } \\
\text { screening measures (e.g. mass testing, mandatory } \\
\text { quarantines) }\end{array}$} \\
\hline & $\begin{array}{l}\text { - Increased risk of rapid export of disease to other parts of } \\
\text { the country and neighboring countries }\end{array}$ & \\
\hline & & \\
\hline \multirow[t]{2}{*}{$\begin{array}{l}\text { Health } \\
\text { communication/education }\end{array}$} & $\begin{array}{l}\text { - Multiple information sources leading to misinformation } \\
\text { and false information might spread quickly }\end{array}$ & $\begin{array}{l}\text { - Unconventional but reliable information channels and } \\
\text { social media can be used for risk communication }\end{array}$ \\
\hline & $\begin{array}{l}\text { - Fear and stigma can discourage voluntary positive health } \\
\text { seeking behaviour }\end{array}$ & - Trust can be built through anti-stigma messages \\
\hline
\end{tabular}

Synthesis by themes revealed that majority of the publications (75\%) predominantly examined COVID-19 response strategies in Africa with a few others looking at the combine spectra of preparedness, response and urbanization. Ten (10) out the 24 synthesized publications primarily focused on COVID-19 urbanization nexus while $29 \%$ primarily focused on health system preparedness for COVID-19 in Africa.

Most recurrent themes were on impact of COVID-19 on health service provision (mental health, maternal and child health services), health logistics and supplies including HIV/AIDS medications. Another most recurrent theme was health systems resilience in Africa towards COVID-19 and future pandemics, followed by spillover effects of COVID-19 response strategies on economies and livelihoods. Discussions on Africa's one-size-fit-all approach to COVID-19 were also apt in many of the publications.

Other recurrent themes were health sector human resources to fight the pandemic and lack of compliance with COVID-19 prevention and safety protocols. One publication emphasized leveraging Africa's past experiences with Ebola and HIV/AIDS in the prevention and control of COVID-19. One other publication examined the nexus between urbanization and COVID-19 in Africa's urban slums and informal settlements (see Fig. 2).

\section{Discussion}

\section{Summary of evidence}

Globally, it has been established that sufficient preparedness for pandemics by countries is a crucial investment since the cost is comparatively smaller than an unmitigated impact of health emergencies like COVID-19. For instance, the global financing gap for health emergency preparedness, estimated at US $\$ 4.5$ billion per year, is miniscule compared with estimated pandemic costs of $\$ 570$ billion per year ${ }^{[26]}$. Health emergency preparedness activities in Africa with more fragile health systems are particularly crucial because of increasing urban populations and the attendant public health implications ${ }^{\text {[27] }}$. Opportunities in urban environments thus need to be leveraged to enhance the preparedness of urban settings for health emergencies like COVID-19. Table 2 presents the challenges and opportunities for urban settings in raising preparedness for public health emergencies in Africa.

In many parts of Europe and the Americas strict COVID-19 prevention and control measures have been enforced including total lockdowns. Unfortunately, many African countries spontaneously adopted same lockdown measures without requisite knowledge of the COVID-19 infection rate and the context-specific relevance of these measures. Ghana for instance observed two weeks partial lockdown in the two most urbanized regions as part of the early control 
measures without sufficient evidence. Unlike other continents, Africa was fortunate to record COVID-19 cases months after other countries recorded cases. The continent thus had the benefit of time and hindsight to prepare and respond differently to the pandemic based on lessons learnt. However, reviewed literature predominantly suggests Africa's response strategies were largely not context-specific. Africa's response strategies can best be described as a carbon copy of interventions adopted in China, other Asian countries, Europe and the Americas, albeit the circumstances and epidemiology of the virus were different. In effect, a "one-size-fit-all" approach was spontaneously adopted. Indeed, some of the COVID-19 response measures were needless and turned out to be ineffective.

Restrictions in social gatherings have also been imposed to control the spread of the virus particularly church activities, funerals, weddings and closure of schools ${ }^{[38]}$. Compulsory wearing face masks and use of hand sanitizers is another pervasive COVID-19 preventive measure in Africa even though strict

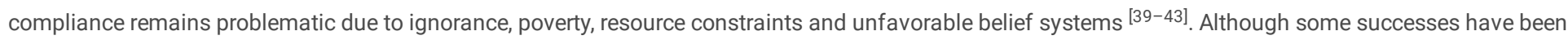
achieved in respect of these response strategies, critics have described them as "one-size-fit-all" and "Western elitist" approach because of irrelevance to Africa's local settings via-a-vis trends in other parts of the world. In many African countries, hand sanitizers have been misconceived as a replacement for regular hand hygiene mainly due to ignorance and lack of education. Likewise, enforcement of social distancing in crowded urban communities is proving to be impracticable just like self-isolation in congested households. These measures have largely been ineffective partly due to poor living standard particularly in urban slums. Also, the "work from home" mantra immediately embraced by already fragile economies in Africa is equally ineffective and unreasonable relative to more resilient economies outside Africa. Over $70 \%$ Africa's workforce is in the informal sector and predominantly engaged in manual labour. In view of this huge informal sector in Africa, the "work from home" policy at the initial phase of the pandemic rather worsen the plight of many citizens already in the lower wealth quintile ${ }^{[44-47]}$.

Other COVID-19 mitigating measures questioned and heavily criticized in Africa are mass closure of schools without established e-learning systems and infrastructure; enforcement of handwashing protocols when over $50 \%$ of households in Africa don't have access to portable water ${ }^{[37]}$; temperature checks of travelers at borders and airports without accounting for asymptomatic carriers of the virus and mass testing capacities.

Moreover, many countries in Africa are still battling with fear-based messaging and misinformation on COVID-19 ${ }^{\text {[48] }}$ similar to Ebola and HIV/AIDS ${ }^{[13]}$ Available literature maintains that misinformation and fear-based communication cause anxiety and possibly deaths ${ }^{[49]}$ of which COVID-19 is not an exception. Over the years, in pandemics response, fear has rarely been a good motivator for people's adherence to safety precautions. Indeed, people generally respond better to calm and fact-based messages/information ${ }^{[49]}$. Unfortunately, many countries in Africa have not performed optimally in respect of COVID19, Ebola and HIV/AIDS and stigma management. In effect, misinformation and fear-based messaging associated with COVID-19 continues to bread stigma which is discouraging infected persons to declare their status which potentially promotes community spread of the virus.

Notwithstanding these lapses Africa is praised for some positives in the COVID-19 fight. For instance, countries with more recent experience with Ebola appear to be leveraging this expertise in response to COVID-19. Liberia, Sierra Leone, Democratic Republic of Congo (DRC) and Guinea are currently re-purposing existing structures used during Ebola as COVID-19 isolation and treatment centres ${ }^{[28,29]}$. In DRC single-patient-transparent cubes originally designed for isolation of Ebola cases re-purposed for COVID-19 isolation and treatment centres ${ }^{[30]}$. Similarly, inter-sectoral collaboration with non-governmental organizations (NGOs), industry players and national security agencies. Likewise, educational institutions, government ministries and religious bodies is being leveraged fight the battle against COVID-19 in many African countries ${ }^{[12,31-36]}$. The role of the media and civil society in propagating health education and communication on COVID-19 prevention and control has equally been phenomenal in Africa ${ }^{[35]}$. In addition, the ingenuity of many African countries in developing locally manufactured handwashing devices and personal protective equipment (PPEs) is especially commended in the bit to promote self-reliance and sustainability in the wake of COVID-19 ${ }^{[37]}$.

Finally, lessons learnt from Ebola in West Africa show that balancing urgent clinical care with the general well-being of the community is the best prescription for containing pandemic outbreaks. In light of this, some African countries incorporated community engagement approach in the prevention and control of COVID-19 [29,50-52]. Some reports suggest that lockdown impositions in Africa were executed with human considerations and social support for the less privileged through community mobilization. These community-centered response strategies have contributed to high compliance with the COVID-19 preventive measures in some countries $[53,54]$.

Irrespective of these important achievements chalked in Africa, the reviewed literature also reports instances of spillover effects arising from the COVID-19 mitigation measures. First, urban dwellers working in the informal sector (and are predominantly labour migrants) are so far the worst affected by COVID-19 in Africa since approximately $85 \%$ of workers in Africa are not on regular wages and do not have the option to work from home ${ }^{[55]}$. During the lockdowns, for these underprivilege majority did not earn a wage throughout the period. The story of the Kenyan widow of many children boiling stones for her children during the lockdown elucidates this point ${ }^{[56]}$.

Furthermore, many countries in Africa recorded an interruption in food chain especially in urban cities which often relied on rural communities for food supplies. Countries like Ghana witnessed an escalation in food prices by nearly $30 \%$ during the partial lockdowns ${ }^{[57,58]}$ due to panic buying and disruptions in food supply chain. Even though lockdowns might have helped curb the virus transmission, these measures also pushed millions of people into extreme poverty to the extent that hunger, rather than COVID-19, had a greater chance of killing already impoverished individuals during the lockdowns. Human rights abuses during lockdowns ${ }^{[39,59]}$ are also excesses that emanated from the COVID-19 response measures in many parts of Africa.

Finally, another spillover effect of the COVID-19 response measures in Africa was the effect on already fragile health systems. Neglect of the public health needs of populations in the wake of COVID-19 has already been reported with unprecedented reduction in health service utilization including HIV/AIDS 
services ${ }^{[60]}$. Utilization of mental health ${ }^{[61-63]}$, maternal/child health and related outpatient department (OPD) services ${ }^{[64,65]}$ have equally been adversely affected in Africa imminent worst consequences post-COVID-19.

\section{Limitations}

This review also includes commentaries, editorials, perspectives and some grey literature because of the novel nature of COVID-19 and the fact that not many empirical literature is yet available, especially on Africa. Africa therefore needs a rigorous research agenda on COVID-19 to inform evidence-based policies during and after the pandemic.

\section{Conclusions}

Countries, particularly in Africa, need to improve health infrastructure, human resources, medical technology to enable them respond adequately to public health emergencies. COVID-19 has taught the world that pandemic preparedness should be prioritized over response. A relatively less expensive yet effective investment should be at the community level. Improving health sector human resource capacity at the primary healthcare level such as community health workers has particularly proven to be an effective approach to early containment of global pandemics.

Trillions of dollars have already been committed ${ }^{[66]}$ in just over 6 months for the COVID-19 response globally. Meanwhile, a COVID-19 vaccine or treatment might take months if not years to become commercially available and accessible to resource poor settings mostly in Africa ${ }^{[67]}$ coupled with the fact that readily available and accessible COVID-19 vaccine today does not guarantee acceptance and adoption in places with shortages of health sector human resources. In effective, a comparative US\$2 billion ${ }^{[67]}$ annual investment to bolster CHWs as a health system strengthening platform for primary care is miniscule compared to the current global cost of health systems response to the current pandemic. These practical nuances elucidate the need for prioritization of efficient and effective community level interventions particularly in resource constrained countries in Africa.

\section{List Of Abbreviations}

AIDS Acquired deficiency disease

COVID-19 Coronavirus disease 2019

HIV Human immune virus

NGOs Non-governmental organizations

OPD Outpatient department

REC Research Ethics Committee

\section{Declarations}

\section{Ethical Approval and Consent to Participate}

No human subjects were used for this review hence no Ethical Clearance required as the University of Health and Allied Sciences Research Ethics Committee (REC) guidelines.

\section{Availability of data and materials}

All required information is contained in the manuscript.

\section{Funding}

There is no funding support for this work

\section{Acknowledgements}

The researcher appreciates and acknowledges important institutional repositories such as the Ghana Health Service (GHS) COVID-19 update platform and likewise the African Centres for Diseases Control (CDC) and the Official website of the World Health Organization (WHO).

\section{Consent for publication}

Not applicable

\section{Competing interests}

Author declares there is no conflict of interest

Authors' contributions 
RKA: provided conceptualization direction, literature search, synthesis and analysis and manuscript write-up.

\section{References}

1. WHO Regional Office for Africa. A second COVID-19 case is confirmed in Africa. 2020. https://www.afro.who.int/news/second-covid-19-caseconfirmedafrica (accessed July 3, 2020)

2. African Union (AU). Africa CDC, Official Website, $24^{\text {th }}$ August, 2020 (accessed from: https://africacdc.org/covid-19/)

3. World Health Organization. (2016). Global report on urban health: equitable healthier cities for sustainable development. WHO Library Cataloguing-inPublication Data. ISBN 9789241565271

4. Ithnin, M., Mohamad nor, N. A. U., Juliana, N., Mohd Effendy, N., Sahar, M. A., Abang Abdullah, K. H., ... \& Mohd Rani, M. D. (2020). Knowledge, attitudes and practices on risk factors of non-communicable diseases (NCDs): a cross-sectional survey among urban and rural adults in Negeri Sembilan, Malaysia. International Journal of Health Promotion and Education, 1-11.

5. Li Q, Guan X, Wu P, et al. Early transmission dynamics in Wuhan, China, of novel coronavirus-infected pneumonia. N Engl J Med 2020; published online Jan 29. DOI:10.1056/NEJMoa2001316.

6. Cho SY, Kang JM, Ha YE, et al. MERS-CoV outbreak following a single patient exposure in an emergency room in South Korea: an epidemiological outbreak study. Lancet 2016; 388: 994-1001.

7. Nikolich-Zugich, J., Knox, K. S., Rios, C. T., Natt, B., Bhattacharya, D., \& Fain, M. J. (2020). SARS-CoV-2 and CoVID-19 in older adults: what we may expect regarding pathogenesis, immune responses, and outcomes. Geroscience, 1-10. Metsky HC, Matranga CB, Wohl S, et al. Zika virus evolution and spread in the Americas. Nature 2017; 546: 411-15

8. Alegbeleye, B. J. (2020). Coronavirus Disease-19 Outbreak: Barriers to Hand Hygiene Practices Among Healthcare Professionals in Sub-Saharan Africa. International Journal of Scientific Advances, 1(1)

9. Bong, C. L., Brasher, C., Chikumba, E., McDougall, R., Mellin-Olsen, J., \& Enright, A. (2020). The COVID-19 Pandemic: Effects on Low- and Middle-Income Countries. Anesthesia and analgesia, 131(1), 86-92. https://doi.org/10.1213/ANE.0000000000004846

10. Armah, F. A., Ekumah, B., Yawson, D. O., Odoi, J. O., Afitiri, A. R., \& Nyieku, F. E. (2018). Access to improved water and sanitation in sub-Saharan Africa in a quarter century. Heliyon, 4(11), e00931.

11. Eberhard, R (2019). Part I (synthesis report): Access to Water and Sanitation in Sub-Saharan Africa, Review of Sector Reforms and Investments, Key Findings to Inform Future Support to Sector Development. Deutsche Gesellschaft für Internationale Zusammenarbeit (GIZ) GmbH. Accessed on $24^{\text {th }}$ August, 2020 from: https://www.oecd.org/water/GIZ_2018_Access_Study_Part\%20I_Synthesis_Report.pdf

12. Gilbert, M., Pullano, G., Pinotti, F., Valdano, E., Poletto, C., Boëlle, P. Y., ... \& Gutierrez, B. (2020). Preparedness and vulnerability of African countries against importations of COVID-19: a modelling study. The Lancet, 395(10227), 871-877.

13. Oyeyemi, S. O., Gabarron, E., \& Wynn, R. (2014). Ebola, Twitter, and misinformation: a dangerous combination? Bmj, 349, g6178.

14. Manguvo, A., \& Mafuvadze, B. (2015). The impact of traditional and religious practices on the spread of Ebola in West Africa: time for a strategic shift. The Pan African Medical Journal, 22(Suppl 1).

15. Bangura, J. B. (2016). Hope in the midst of death: Charismatic spirituality, healing evangelists and the Ebola crisis in Sierra Leone. Missionalia, 44(1), 218.

16. James, P. B., Wardle, J., Steel, A., \& Adams, J. (2020). Ebola survivors' healthcare-seeking experiences and preferences of conventional, complementary and traditional medicine use: a qualitative exploratory study in Sierra Leone. Complementary Therapies in Clinical Practice, $39,101127$.

17. Balde, A. (2016). How elements of culture have contributed to the construction of health meanings in regards to the 2014 Ebola outbreak (Doctoral dissertation).

18. PARK, C. (2020). Traditional funeral and burial rituals and Ebola outbreaks in West Africa: A narrative review of causes and strategy interventions. Journal of Health and Social Sciences, 5(1), 073-090.

19. Neiderud C. J. (2015). How urbanization affects the epidemiology of emerging infectious diseases. Infection ecology \& epidemiology, $5,27060$. https://doi.org/10.3402/iee.v5.27060

20. VOA: Ghana's Decision to Lift Partial COVID-19 Lockdown Criticized by Some. April $20^{\text {th }}, 2020$. https://www.voanews.com/africa/ghanas-decision-liftpartial-covid-19-lockdown-criticized-some

21. The Guardian: Easing of lockdown a relief to Ghana's poor - despite fears it is premature. May, 2020. https://www.theguardian.com/globaldevelopment/2020/may/03/coronavirus-easing-of-lockdown-a-relief-to-ghanas-poor-despite-fears-it-is-premature

22. New York Times: Here's the Biggest Thing to Worry about with Coronavirus, $12^{\text {th }}$ March, 2020. https://www.nytimes.com/2020/03/12/upshot/coronavirus-biggest-worry-hospital-capacity.html

23. Monitor: ICU bed capacity in Uganda, $18^{\text {th }}$ March, 2020. https://www.monitor.co.ug/News/National/ICU-bed-capacity-Uganda/688334-5495822dkw5rc/index.html

24. Atumanya, P., Sendagire, C., Wabule, A., Mukisa, J., Ssemogerere, L., Kwizera, A., \& Agaba, P. K. (2020). Assessment of the current capacity of intensive care units in Uganda; A descriptive study. Journal of critical care, 55, 95-99.

25. Afulani, P. A., Gyamerah, A. O., Aborigo, R., Nutor, J., Malechi, H., Laar, A., ... \& Awoonor-Williams, J. J. (2020). Perceived preparedness to respond to the COVID-19 pandemic: A study with healthcare workers in Ghana. medRxiv. 
26. Lee, V. J., Ho, M., Kai, C. W., Aguilera, X., Heymann, D., \& Wilder-Smith, A. (2020). Epidemic preparedness in urban settings: new challenges and opportunities. The Lancet Infectious Diseases, 20(5), 527-529.

27. World Health Organization. (2020). Support to countries for strengthening public health capacities required under the International Health Regulations (2005): WHO Lyon Office, Department of Country Health Emergency Preparedness and IHR: activity report 2018-2019.

28. Chersich, M. F., Gray, G., Fairlie, L., Eichbaum, Q., Mayhew, S., Allwood, B., ... \& Haghighi, M. M. (2020). CoVID-19 in Africa: care and protection for frontline healthcare workers. Globalization and Health, 16, 1-6.

29. Ayebare, R., Waitt, P., Okello, S., Kayiira, M., Ajok, M. A., Nakatudde, I., ... \& Lamorde, M. (2020). Leveraging investments in Ebola preparedness for COVID-19 in Sub-Saharan Africa. AAS Open Research, 3.

30. Alliance for international medical action (ALIMA). (2016). The concept: bring innovation to the treatment of infectious diseases. https://www.alimango.org/uploads/831a19bc0a7022906a7773cb8f4c36e9.pdf?_ga=2.184743786.2119725034.1598310564-704145836.1598310564

31. Martinez-Alvarez, M., Jarde, A., Usuf, E., Brotherton, H., Bittaye, M., Samateh, A. L., ... \& Roca, A. (2020). COVID-19 pandemic in west Africa. The Lancet Global Health, 8(5), e631-e632.

32. Paintsil, E. (2020). COVID-19 threatens health systems in sub-Saharan Africa: the eye of the crocodile. The journal of clinical investigation, 130(6).

33. Nepomnyashchiy, L., Dahn, B., Saykpah, R., \& Raghavan, M. (2020). COVID-19: Africa needs unprecedented attention to strengthen community health systems. The Lancet, 396(10245), 150-152.

34. Cash, R., \& Patel, V. (2020). Has COVID-19 subverted global health? The Lancet, 395(10238), 1687-1688.

35. Rosenthal, P. J., Breman, J. G., Djimde, A. A., John, C. C., Kamya, M. R., Leke, R. G., ... \& Bausch, D. G. (2020). COVID-19: shining the light on Africa. The American Journal of Tropical Medicine and Hygiene, 102(6), 1145.

36. Wilkinson, A. (2020). Local response in health emergencies: key considerations for addressing the COVID-19 pandemic in informal urban settlements. Environment and Urbanization, 0956247820922843.

37. Arakpogun, E., El Sahn, Z., Prime, K. S., Gerli, P., \& Olan, F. (2020). Africa's Resilience in the Face of COVID-19 Pandemic: Let's Talk about It!. Available at SSRN 3640311.

38. Wango, G. M., Wairire, G., \& Kimamo, C. (2020). Patterns of Development of COVID-19 in Low-and Middle-Income Countries: Suggested Psychological Intervention Strategies.

39. Iwuoha, V. C., \& Aniche, E. T. (2020). Covid-19 lockdown and physical distancing policies are elitist: towards an indigenous (Afro-centred) approach to containing the pandemic in sub-urban slums in Nigeria. Local Environment, 1-10.

40. Roser, M., Ritchie, H., Ortiz-Ospina, E., \& Hasell, J. (2020). Coronavirus pandemic (COVID-19). Our World in Data.

41. Ahmed, M. A., Jouhar, R., Ahmed, N., Adnan, S., Aftab, M., Zafar, M. S., \& Khurshid, Z. (2020). Fear and practice modifications among dentists to combat Novel Coronavirus Disease (COVID-19) outbreak. International journal of environmental research and public health, $17(8), 2821$.

42. Junior, E. K. D., \& Dei, O. A. (2020). Adherence to social distancing and wearing of masks within public transportation during the COVID 19 pandemic. Transportation Research Interdisciplinary Perspectives, 100191.

43. Nyarko, R. O., Boateng, E., Kahwa, I., Boateng, P. O., \& Asare, B. (2020). The Impact on Public Health and Economy Using Lockdown as a Tool against COVID-19 Pandemic in Africa: A Perspective. J Epidemiol Public Health Rev, 5(3).

44. Irlacher, M., \& Koch, M. (2020). Working from home, wages, and regional inequality in the light of Covid-19.

45. Bick, A., Blandin, A., \& Mertens, K. (2020). Work from home after the COVID-19 Outbreak.

46. Otu, A., Ebenso, B., Labonte, R., \& Yaya, S. (2020). Tackling COVID-19: Can the African continent play the long game?. Journal of Global Health, 10(1).

47. Ataguba, J. E. (2020). COVID-19 pandemic, a war to be won: understanding its economic implications for Africa.

48. Kigatiira, K. K. (2020). Efficacy of fear appeals on adoption of covid-19 preventive measures: a case of boda boda riders in Nairobi county, Kenya. International Journal of Research-Granthaalayah, 8(6), 219-228.

49. Bedrosian, S. R. (2016). Lessons of risk communication and health promotion-West Africa and United States. MMWR supplements, 65.

50. Nachega, J. B., Mbala-Kingebeni, P., Otshudiema, J., Mobula, L. M., Preiser, W., Kallay, O., ... \& Ahuka-Mundeke, S. (2020). Responding to the Challenge of the Dual COVID-19 and Ebola Epidemics in the Democratic Republic of Congo-Priorities for Achieving Control. The American journal of tropical medicine and hygiene, 103(2), 597-602.

51. Gilmore, B., Ndejjo, R., Tchetchia, A., de Claro, V., Nyamupachitu-Mago, E., Lopes, C. A., \& Bhattacharyya, S. (2020). Community engagement for CoVID-19 prevention and control: A Rapid Evidence Synthesis. medRxiv.

52. Estifanos, A. S., Alemu, G., Negussie, S., Ero, D., Mengistu, Y., Addissie, A., ... \& Kotecho, M. G. (2020). 'I exist because of we': shielding as a communal ethic of maintaining social bonds during the COVID-19 response in Ethiopia. BMJ Global Health, 5(7), e003204.

53. Mobula, L. M., Samaha, H., Yao, M., Gueye, A. S., Diallo, B., Umutoni, C., ... \& Bruni, E. (2020). Recommendations for the CoVID-19 Response at the National Level Based on Lessons Learned from the Ebola Virus Disease Outbreak in the Democratic Republic of the Congo. The American Journal of Tropical Medicine and Hygiene, tpmd200256.

54. Abideen, A.Z., Mohamad, F.B. and Hassan, M.R. (2020), "Mitigation strategies to fight the COVID-19 pandemic-present, future and beyond", Journal of Health Research, Vol. ahead-of-print No. ahead-of-print. https://doi.org/10.1108/JHR-04-2020-0109

55. The Economist: Continental contagion, Africa is woefully ill-equipped to cope with covid-19, $29^{\text {th }}$ March, 2020. https://www.economist.com/middleeastand-africa/2020/03/26/africa-is-woefully-ill-equipped-to-cope-with-covid-19 
56. BBC: Coronavirus: Kenyans moved by widow cooking stones for children, $30^{\text {th }}$ April, 2020. https://www.bbc.com/news/world-africa52494404\#: :text=Kenyans\%20have\%20rallied\%20to\%20the,they\%20waited\%20for\%20their\%20meal.

57. Alliance for Science: COVID-19 virus spread prompts food insecurity fears in Africa, $26^{\text {th }}$ March, 2020. https://allianceforscience.cornell.edu/blog/2020/03/covid-19-virus-spread-prompts-food-insecurityfears-in-africa/

58. IFPRI: How much will global poverty increase because of COVID-19?. 20 th March, 2020. https://www.ifpri.org/blog/how-much-will-global-poverty-increasebecause-covid-19.

59. Amadasun, S. (2020). COVID-19 palaver: Ending rights violations of vulnerable groups in Africa. World Development, 105054.

60. Jewell, B. L., Mudimu, E., Stover, J., Ten Brink, D., Phillips, A. N., Smith, J. A., ... \& Bansi-Matharu, L. (2020). Potential effects of disruption to HIV programmes in sub-Saharan Africa caused by COVID-19: results from multiple mathematical models. The Lancet HIV. https://doi.org/10.1016/S23523018(20)30211-3

61. World Health Organization. (2020). Coronavirus disease (COVID-19): situation report, 182.

62. Joska, J. A., Andersen, L., Rabie, S., Marais, A., Ndwandwa, E. S., Wilson, P., ... \& Sikkema, K. J. (2020). COVID-19: Increased Risk to the Mental Health and Safety of Women Living with HIV in South Africa. AIDS and Behavior, 1.

63. Kim, A. W., Nyengerai, T., \& Mendenhall, E. (2020). Evaluating the mental health impacts of the covid-19 pandemic in urban South Africa: perceived risk of COViD-19 infection and childhood trauma predict adult depressive symptoms. medRxiv.

64. Akseer, N., Kandru, G., Keats, E. C., \& Bhutta, Z. A. (2020). COVID-19 pandemic and mitigation strategies: implications for maternal and child health and nutrition. The American journal of clinical nutrition, 112(2), 251-256.

65. Roberton, T., Carter, E. D., Chou, V. B., Stegmuller, A. R., Jackson, B. D., Tam, Y., ... \& Walker, N. (2020). Early estimates of the indirect effects of the COVID-19 pandemic on maternal and child mortality in low-income and middle-income countries: a modelling study. The Lancet Global Health.

https://doi.org/10.1016/S2214-109X(20)30229-1

66. Cornish L. (2020). Interactive: who's funding the COVID-19 response and what are the priorities. Devex, May 28, 2020. https://www.devex.com/news/ interactive-who-s-funding-the-covid-19-response-and-what-are-thepriorities-96833 (accessed June 25, 2020).

67. Atherly D. (2020). Opinion: to deliver a COVID-19 vaccine equitably, we must start planning now. Devex, May 7, 2020. https://www.devex.com/news/opinionto-deliver-a-covid-19-vaccine-equitably-we-must-start- planningnow-97168 (accessed June 25, 2020).

68. USAID Center for Innovation and Impact, Financing Alliance for Health, Dalberg Advisors. (2020). Strengthening primary health care through community health workers: closing the $\$ 2$ billion gap. Nov 28, 2017. https://www. usaid.gov/cii/strengthening-primary-health-care-through-communityhealth-workersclosing-2-billion-gap (accessed June 25, 2020).

\section{Figures}




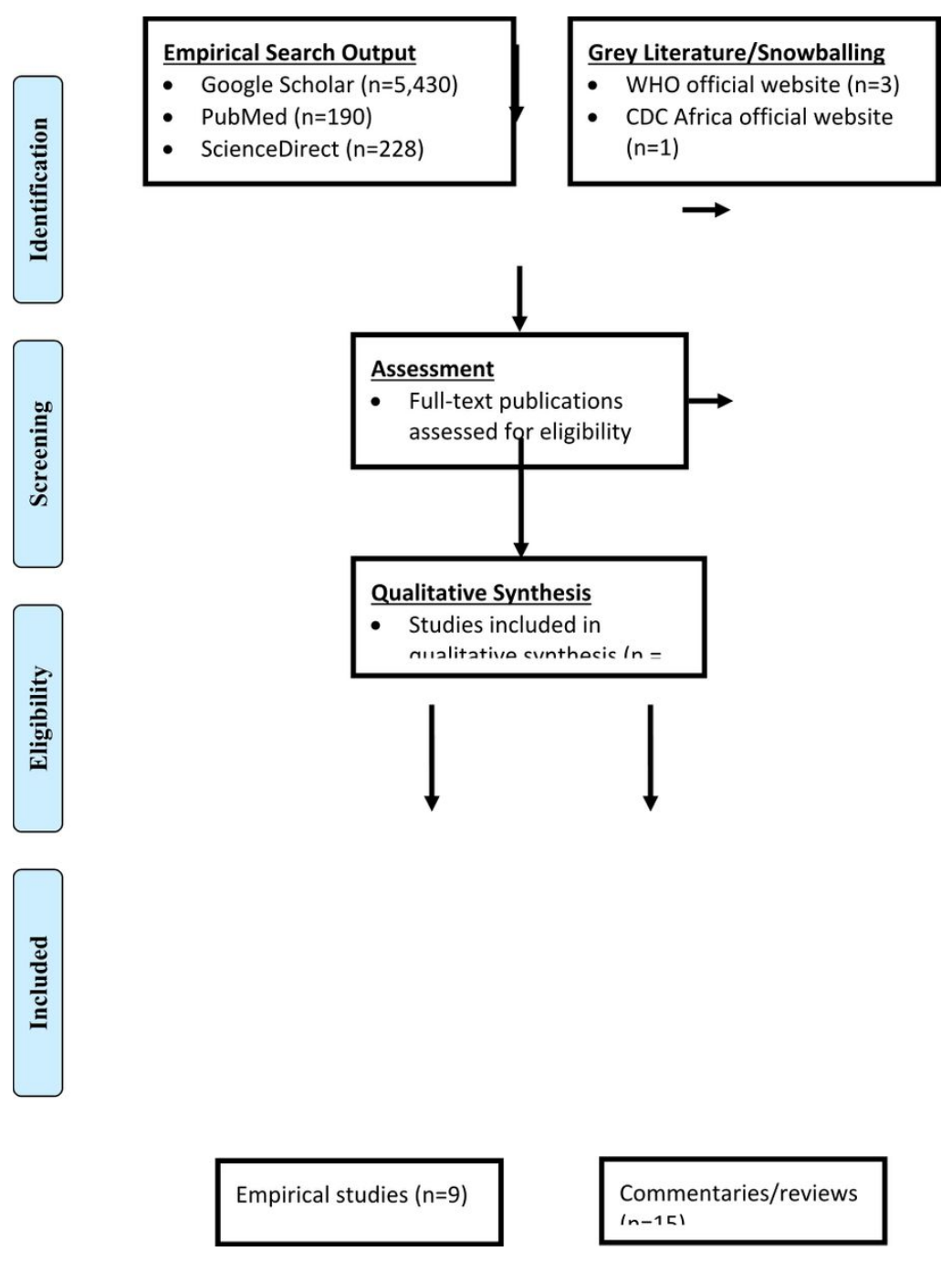

Figure 1

PRISMA Flow Chart (2009) Legend: Source, Moher D, Liberati A, Tetzlaff J, Altman DG, The PRISMA Group (2009). Preferred Reporting Items for Systematic Reviews and Meta-Analyses: The PRISMA Statement. PLoS Med 6(7): e1000097. doi:10.1371/journal.pmed1000097

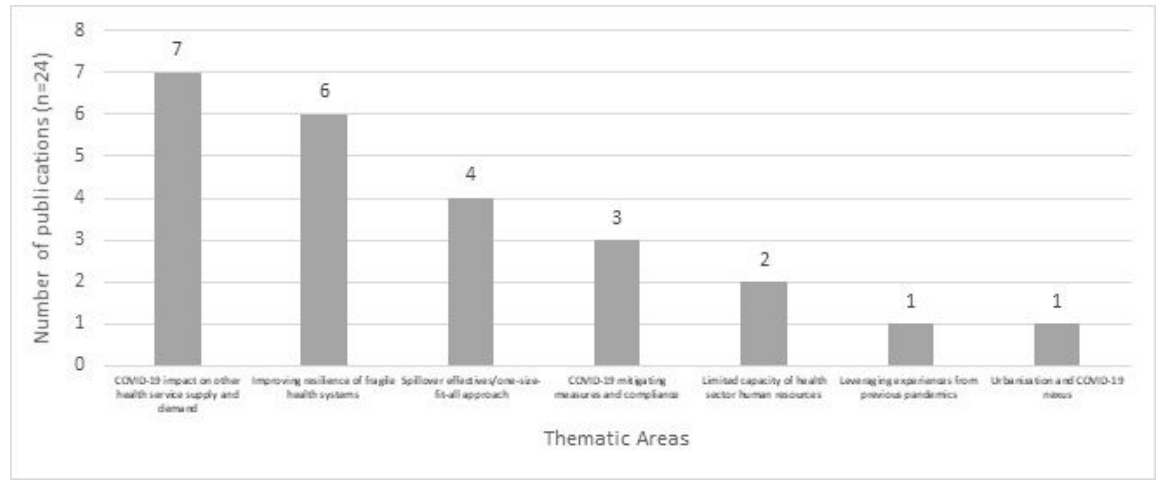

Figure 2

Recurrence of main themes from reviewed literature Legend: Source, aggregated by authors based on reviewed literature (2020)

\section{Supplementary Files}

This is a list of supplementary files associated with this preprint. Click to download.

- supplement6.doc 